\title{
SENSORY AND PHYSICOCHEMICAL STUDY OF CARROT LEAF SPONGE
}

\author{
CAKE
}

Aline Cristini dos Santos ${ }^{1}$, Natália Norika Yassunaka ${ }^{1}$, Suelen Pereira Ruiz ${ }^{1}$, Vanessa Vivian de Almeida Schneider ${ }^{2}$, Jesuí Vergílio Visentainer ${ }^{1}$, Grasiele Scaramal Madrona ${ }^{1 *}$

*grasiele@yahoo.com

${ }^{1}$ Universidade Estadual de Maringá - UEM;

2Universidade Tecnológica Federal do Paraná - UTFPR.

DOI: http://dx.doi.org/10.14685/rebrapa.v4i2.121

\begin{abstract}
In this study, carrot leaf was incorporated into sponge cake. The objectives were the development of cakes and the sensory and physicochemical evaluation of them. Three products were developed: $i$. without carrot leaf addition (WOCL); ii. with carrot leaf addition (WCL); iii. with carrot leaf and lemon zest addition (CLLZ). Two cakes were sensory evaluated by a panel of 173 children (aged 5 to 13 years) by hedonic scale smiley faces of five points. Data were evaluated by ANOVA and Tukey's Test at 5\% of significance. WCL and CLLZ scores were 4.66 and 4.56, respectively, and they were corresponded to an excellent acceptance. The most of the results of proximate composition was not statistically different among

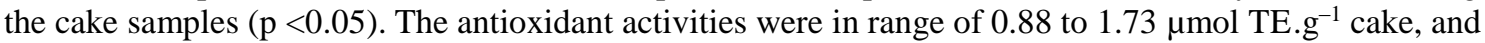
they were statistically different from each other. There was no difference among the texture values; however, there was a statistically significant increase of antioxidant activity in the WCL and CLLZ compared to WOCL. In light of this, the use of carrot leaf, especially in new infant cake products is an opportunity to avoid the waste, and add value to carrot leaf.
\end{abstract}

Keywords: Sensorial acceptability, texture/color parameters, antioxidant activity, by-products, food development.

Estudo Sensorial e Físico-Químico de Bolo com Folha de Cenoura: Neste estudo, folha de cenoura foi incorporada em bolo. Os objetivos foram o desenvolvimento e as avaliações sensorial e físico-químicas de bolo com folha de cenoura. Três produtos foram desenvolvidos: i. sem adição de folha de cenoura (WOCL); ii. com adição de folha de cenoura (WCL) e iii. com adição de folha de cenoura e raspa de limão (CLLZ). Dois bolos foram avaliados sensorialmente por um painel de 173 crianças com idades entre 5 e 13 anos por meio de escala hedônica facetada. Os dados foram avaliados por ANOVA e Teste de Tukey a 5\% de significância. WCL e CLLZ obtiveram notas de 4,66 e 4,56, respectivamente, o que correspondeu a uma excelente aceitação. A maioria dos resultados para composição proximal não foi estatisticamente diferente entre as amostras de bolo ( $\mathrm{p}<0,05$ ). As atividades antioxidantes estiveram no intervalo de 0,88 a $1,73 \mu \mathrm{mol}$ ET. $\mathrm{g}^{-1}$ bolo, e esses valores diferiram significativamente entre si. Não houve diferenças entre os valores de textura; contudo, houve aumento significativo na atividade antioxidante de WCL e CLLZ comparado à WOCL. Portanto, o uso de folha de cenoura, especialmente em novas formulações de bolo destinados à alimentação infantil é uma forma de evitar o desperdício e agregar valor a folha de cenoura.

Palavras-chave: aceitabilidade sensorial, parâmetros de cor e textura, atividade antioxidante, subprodutos, desenvolvimento de alimentos.

\section{Introduction}

The bakery industry is one of the largest organized food industries all over the world and in particular biscuits, crackers and cakes are among the most popular products because of their convenience, ready to eat foam, and long shelf life (GUPTA; BAWA; SEMWAL, 2009). Among the bakery products consumed, cakes are particularly popular and associated in the consumer's 
mind as a delicious product (ZHANG et al., 2012). The major ingredients used in the preparation of sponge cakes are wheat flour, egg and sugar.

In order to prevent the oxidative deterioration of fats and oils in processed food, antioxidants are used as food additives and some natural antioxidants were effective in enhancing the shelf life of bakery products but less effective than synthetic antioxidants (NANDITHA; PRABHASANKAR, 2009). There is a great demand for the use of new natural antioxidants in foods, especially, in bakery products (LU et al., 2010).

In recent decades, many studies have been performed regarding the beneficial effects of natural antioxidants on health (BLOCK; LANGSETH, 1994; BLASA et al., 2010). Antioxidants present in food can help to limit the damage of degenerative diseases by disabling free radicals and other harmful reactive species and by stimulating body's own defense systems to combat the disease by using these groups of protective chemicals (SCALBERT et al, 2005; SALAWU; SANNI; AKINDAHUNSI, 2013).

Agricultural by-products are attractive sources of natural antioxidants. The use of fruit and vegetable byproducts as natural food additives has recently been suggested, due to their richness in polyphenols, carotenoids or others bioactive compounds (AYALAZAVALA et al., 2011; O'SHEA; ARENDT; GALLAGHER, 2012; AL-SAYED; AHMED, 2013).

Commonly, carrot leaf is a by-product not consumed in Brazil. However, the carrot leaf was reported as rich in essential fatty acids (ALMEIDA et al., 2009), antioxidants (LEITE et al., 2011), fibers and minerals (PEREIRA et al., 2003). Furthermore, dehydrated carrot leaf was added in food as an alternative source of antioxidants and nutrients (BOROSKI et al., 2011).

Nutritional properties of bakery products may be improved with natural bioactive components found in by-products. Bakery products such as sponge cakes have high consumer acceptance and could be used for delivering bioactive compounds into the human diet (MORAES et al., 2010). Although cakes are not considered basic food, such as bread, they are accepted and consumed by people of different ages (BORGES et al., 2006). Recently, researches involving addition of functional components such as fibers, natural antioxidants and oligosaccharides in sponge cakes have been reported (KIM et al., 2012; LU et al., 2010, RONDA et al., 2005).

In the present study, carrot leaf was incorporated into sponge cake. The objectives were the development a new product, a sponge cake, and its sensory and physicochemical evaluation.

\section{Material and Methods}

\subsection{Materials}

The ingredients and packaging for cakes were obtained commercially in supermarkets from Maringá (PR). Carrot leaf was provided by a local producer and the raw materials used were from the same batch.

The reagents DPPH (1,1-diphenyl-2-picrylhydrazyl) and Trolox (6-hydroxy-2,5,7,8-tetramethylchroman-2carboxylic acid) were purchased from Sigma. The others reagents were of analytical grade.

The production of sponge cakes was performed at the laboratory of Food Technology from Universidade Estadual de Maringá, taking care with the hygiene and sanitation of materials, environment and manipulation of the ingredients in all process stages.

\subsection{Preparation of Sponge Cakes}

Three products were developed: i. without carrot leaf addition (WOCL); ii. with carrot leaf addition (WCL) and iii. with carrot leaf and lemon zest addition (CLLZ). $50 \mathrm{~g}$ of "in natura" carrot leaf was used (WCL and CLLZ formulations) based in laboratorial tests performed during the experiment.

Table 1- Formulations of sponge cakes (g/100g of raw batter).

\begin{tabular}{cccc}
\hline Ingredients & WOCL & WCL & CLLZ \\
\hline Wheat Flour & 31.5 & 30.8 & 30.7 \\
Sugar & 31.5 & 30.8 & 30.7 \\
Soybean Oil & 11.0 & 10.8 & 10.8 \\
Lemon Zest & - & - & 0.3 \\
Carrot Leaf & - & 3.8 & 3.8 \\
Baking Powder & 0.6 & 0.6 & 0.6 \\
Milk* & 9.6 & 7.8 & 7.7 \\
Eggs & 15.8 & 15.4 & 15.4 \\
\hline
\end{tabular}

\footnotetext{
* Due to the addition of carrot leaves which supplies water to the batter, it was necessary to remove milk from the two formulations.
} 
The preparation procedure of sponge cakes was according to Rodríguez-Garcia et al. (2012) with some modifications. Fresh eggs were broken and separated into two parts: albumen and yolk. Albumen was whipped for 1 min with a wire whisk in a laboratory mixer and reserved. Sugar, egg yolk, oil, milk, lemon zest (CLLZ formulation) and carrot leaf (WCL and CLLZ formulations) were crushed for $2 \mathrm{~min}$ and homogenized with the whipped albumen. Wheat flour and baking powder were added and mixed for $1 \mathrm{~min}$. The mixture was mixed again and poured into greased pan with oil and wheat flour and baked in a pre-heated oven at $200{ }^{\circ} \mathrm{C}$ for 40 minutes. The cakes were cooled for $3 \mathrm{~h}$ at room temperature $\left(25^{\circ} \mathrm{C}\right)$ prior to use in the experiments. The formulation of all types of cake is summarized in Table 1.

\subsection{Sensory Evaluation}

The products, WLC and CLLZ were sensorial evaluated by 173 untrained panelists, formed by children aged between 5 and 13 years, from a elementary school located at the Munhoz de Melo city (Paraná State). To evaluate the overall acceptability of the samples, it was used the Hedonic Smiley scale test structured with five points, in which the extremes corresponded to Dislike a lot (1) and Like a lot (5). A standardized amount $4.0 \mathrm{~g}$ of each sample was offered into plastic packages coded by colored tapes of monadic form. Packaging with red ribbons contained WLC and yellow CLLZ. The cakes were arranged in their natural form, without additional ingredients and offered at room temperature. Along sensory evaluation, the panel received the evaluation form and was served water between the sensory tests for cleaning the palate. Figure 1 shows the form with the Hedonic scale used in the sensory evaluation of sponge cakes.

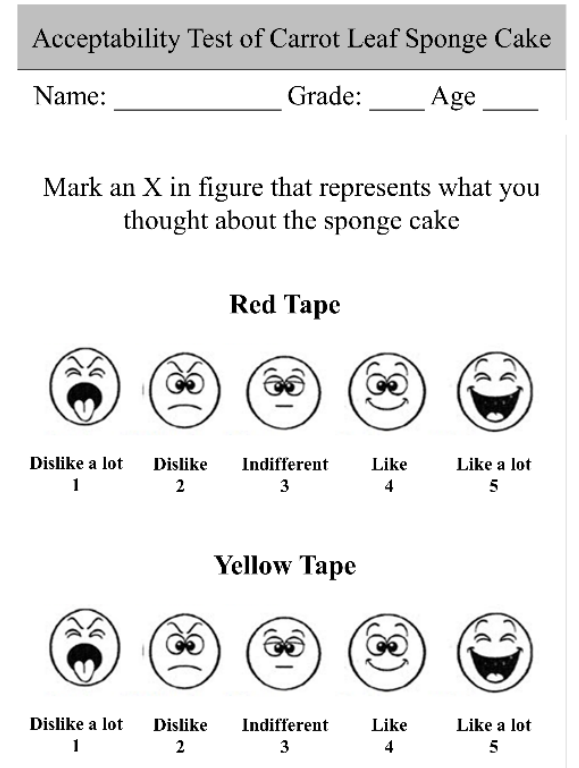

Figure 1. Sensory evaluation form to carrot leaf sponge cake.

\subsection{Proximate composition and antioxidant activity}

Moisture, ash, and protein contents were determined in accordance with AOAC (1997). The total lipids were extracted by the Bligh and Dyer (1959) method. Carbohydrate content was calculated by difference: 100 $-(\%$ moisture $+\%$ ash $+\%$ protein $+\%$ total lipids $)$. The energy value was calculated by adding protein and total carbohydrate multiplied by $4\left(\mathrm{kcal} . \mathrm{g}^{-1}\right)$ added to the total lipids content multiplied by factor 9 (kcal.g-1), i.e., energy value, $\mathrm{kcal}=[(4 \times \%$ protein $)+(4 \times \%$ carbohydrate $)+(9 \times \%$ total lipids $)]$ (ANVISA, 2001). Analyses were performed in triplicate.

Methanolic extracts were prepared using $10 \mathrm{~g}$ of each sample (WCL, CLLZ and WOCL) in $100 \mathrm{~mL}$ of methanol under magnetic stirring for $1 \mathrm{~h}$ (BOROSKI et $a l ., 2011)$. After filtered, the extracts were concentrated under reduced pressure at $40{ }^{\circ} \mathrm{C}$ and used to determine antioxidant activity.

The antioxidant activity of the sponge cakes was assessed through their free radical-scavenging effect on the 1,1-diphenyl-2-picrylhydrazyl (DPPH) radical based on the method proposed by Brand-Williams, Cuvelier e Berset (1995), modified. $600 \mathrm{mg}$ of sponge cake extract were solubilized in $2 \mathrm{~mL}$ of methanol. $20 \mu \mathrm{L}$ of that solution were mixed with $2 \mathrm{~mL}$ of DPPH $\bullet$ methanolic $\left(6.25 \times 10-5\right.$ mol. $\left.\mathrm{L}^{-1}\right)$ and the mixture was kept in the dark for $30 \mathrm{~min}$. The absorbance was measured at 517 $\mathrm{nm}$ in a spectrophotometer model Genesys $10 \mathrm{uv}$ (Thermo Scientific, Madison, USA). Methanol was used as blank. Calibration curve was obtained from methanolic solutions of Trolox (6-hydroxy-2,5,7,8tetramethylchroman-2-carboxylic acid). Antioxidant

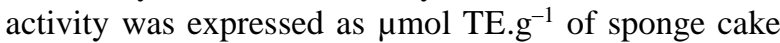
and the results were performed in triplicate.

\subsection{Color}

Color was measured for the three formulations (WCL, CLLZ and WOCL) using a colorimeter Minolta CR-400 (Konica Minolta). The samples were evaluated using three parameters, and results were expressed in $\mathrm{L}^{*}, \mathrm{a}^{*}$ and $\mathrm{b}^{*}$ represented by the CIE $\mathrm{L}^{*} \mathrm{a} * \mathrm{~b} *$ model (Commission International Illuminant). The parameter $\mathrm{L}^{*}$ defines the lightness $[\mathrm{L}=0$ (black); $\mathrm{L}=100$ (white)] and $\mathrm{a}^{*}$ and $\mathrm{b}^{*}$ are responsible for the chromaticity $\left(+\mathrm{a}^{*}\right.$ $-a^{*}$ red and green; $+b^{*}-b *$ yellow and blue). For each treatment, the determinations were performed in triplicate and the results expressed as mean (MCGUIRE, 1992).

\subsection{Texture}

After cooling the cakes at room temperature for $3 \mathrm{~h}$, pieces were cut from the center of each cake $(3 \times 3 \times 3$ $\mathrm{cm})$. The crust of the cake samples was removed in the 
cake texture determinations. The measures were conducted in a texture analyzer (TA-XTplus Texture Analyzer, Stable Micro Systems, Surrey, UK). The texture analysis measurements of the sponge cake samples were taken from double compression, with a cylinder probe $(46 \mathrm{~mm})$. The parameters used in the test were: i. mode: compression; ii. pre-test speed: $0.5 \mathrm{~mm}$ $\mathrm{s}^{-1}$; iii. test speed: $1 \mathrm{~mm} \mathrm{~s}^{-1}$; iv. post-test speed: $10 \mathrm{~mm}$ $\mathrm{s}^{-1}$; v. distance: $15 \mathrm{~mm}$; vi. strength: $30 \mathrm{~g}$. The results were expressed in kgf (kilogram-force) and were represented by the mean of three replicates.

\subsection{Statistics}

Results were statistically analyzed by ANOVA at a significance level of $5 \%$ ( $p<0.05)$ (MONTEIRO, 2005) using the software Statistica 5.0 (Statsoft, Tulsa, USA).

\section{Results and Discussion}

\subsection{Acceptance Test}

The study included 173 healthy elementary school students of a municipal school in the Munhoz de Melo city, where $51 \%$ of students were males and $49 \%$ females. It was observed that the most test answers focused on the last score of the hedonic scale, corresponding to "Like a lot", with $79.2 \%$ of responses for WCL and $76.3 \%$ for CLLZ. Analyzing the acceptance of the WCL, it can be considered that the results were satisfactory, since $16.2 \%$ of the responses were reported as "Like", 0\% indicated as "Indifferent", $0.6 \%$ to "Dislike" and only $4.0 \%$ indicated as "Dislike a lot". The same pattern was observed to the sample CLLZ, the percentage of responses regarding "good" was $13.3 \%$, and only $4.0 \%, 2.9 \%$ and $3.5 \%$, indicated as "Indifferent", "Dislike" and "Dislike a lot", respectively. The WCL had an average of $4.66 \pm 0.86$ acceptance, which means that most of the tasters "Like" product.
Similarly, CLLZ obtained an average of $4.56 \pm 0.96$, indicating in general that it also had great acceptance tasted. In addition, sensory evaluation in this study showed that there was no statistically significant difference between the samples, and that the use of carrot leaf as optional ingredient in sponge cakes would be a great opportunity to avoid the waste, and the introduction of a healthy food without the addition of food additives.

\subsection{Chemical Analyses}

Chemical analyses were performed in the three sponge cake formulations: WOCL, WCL and CLLZ. Mean contents values (\%) of moisture, ash, protein, total lipids and carbohydrates are showed in Table 2, as well as energy (kcal) and antioxidant activity values. Significant differences were observed between WOCL and WCL sponge cakes, to moisture and ash parameters $(\mathrm{p}<0.05)$. On the other hand, no significant differences were observed to protein, total lipids, carbohydrates and energy parameters in three studied formulations. That observation suggests similarity on basic nutritional composition of the cakes.

Kim et al. (2012) reported moisture values in the range of $30-32 \%$ and total fat between 7.5 and $7.9 \%$ in fiberenriched sponge cake, while our mean values to moisture and total lipids were $15.8 \%$. According to $\mathrm{Lu}$ et al. (2010), the mean results to proximate composition of green tea sponge cake were in the range of 30.3$30.8 \%$ to moisture value; $7.0-8.0 \%$ to protein; $10.2-$ $10.3 \%$ to fat; $0.9-1.2 \%$ to ash and $50.3-51.3 \%$ to carbohydrate. Protein mean value of our sponge cakes (7.2\%) are similar to that of Lu et al. (2010), as well as ash mean value $(0.9 \%)$. The energy values to sponge cake of the present study (between 403 and 424 $\mathrm{kcal} / 100 \mathrm{~g}$ ) were also different of values reported by Kim et al. (2012), in the range of $270-280 \mathrm{kcal} / 100 \mathrm{~g}$.

The most significant and important difference among the three cake formulations were observed in antioxidant activity.

Table 2- Proximate composition, energy and antioxidant activity of three sponge cake formulations.

\begin{tabular}{lccc}
\hline Sponge Cake/ parameter & WOCL & WCL & CLLZ \\
\hline Moisture (\%) & $13.64^{\mathrm{a}} \pm 1.55$ & $17.75^{\mathrm{b}} \pm 0.62$ & $16.00^{\mathrm{ab}} \pm 0.14$ \\
Ash (\%) & $0.86^{\mathrm{a}} \pm 0.04$ & $0.94^{\mathrm{b}} \pm 0.03$ & $0.90^{\mathrm{a}} \pm 0.01$ \\
Protein $(\%)$ & $7.24^{\mathrm{a}} \pm 0.47$ & $7.31^{\mathrm{a}} \pm 0.38$ & $7.07^{\mathrm{a}} \pm 0.11$ \\
Lipids (\%) & $16.39^{\mathrm{a}} \pm 4.23$ & $15.46^{\mathrm{a}} \pm 2.91$ & $15.57^{\mathrm{a}} \pm 2.06$ \\
Carbohydrates* $(\%)$ & $62.03^{\mathrm{a}} \pm 5.73$ & $58.55^{\mathrm{a}} \pm 2.65$ & $60.29^{\mathrm{a}} \pm 2.08$ \\
Energy (kcal/100g) & $424^{\mathrm{a}} \pm 15$ & $403^{\mathrm{a}} \pm 17$ & $410^{\mathrm{a}} \pm 10$ \\
Antioxidant Activity $\left(\boldsymbol{\mu m o l ~ T E . g ^ { - 1 } )}\right.$ & $0.88^{\mathrm{a}} \pm 0.08$ & $1.48^{\mathrm{b}} \pm 0.05$ & $1.73^{\mathrm{c}} \pm 0.10$
\end{tabular}

Results given as mean \pm SD ( $\mathrm{n}=3)$. Different letters in same line indicate a statistically significant difference by Tukey’s test ( $\mathrm{p}<0.05)$. $*$ Total carbohydrates were calculated by difference: $100-(\%$ moisture $+\%$ ash $+\%$ protein $+\%$ total lipids $)$. 
Table 3. Values of the analyses of chromaticity and texture parameters in samples of cakes.

\begin{tabular}{ccccc}
\hline \multirow{3}{*}{ Sponge cakes } & \multicolumn{3}{c}{ Parameters } \\
\cline { 2 - 4 } & \multicolumn{3}{c}{ Color } & Texture (kg.f) \\
\cline { 2 - 4 } $\mathbf{L}^{*}$ & $\mathbf{a}^{*}$ & $\mathbf{b}^{*}$ & \\
\hline WOCL & $64.3^{\mathrm{a}} \pm 1.5$ & $-1.1^{\mathrm{a}} \pm 0.4$ & $23.7^{\mathrm{c}} \pm 0.7$ & $1.44^{\mathrm{a}} \pm 0.28$ \\
WCL & $50.2^{\mathrm{b}} \pm 0.7$ & $-5.9^{\mathrm{b}} \pm 0.1$ & $30.2^{\mathrm{b}} \pm 0.8$ & $1.31^{\mathrm{a}} \pm 0.21$ \\
CLLZ & $52.2^{\mathrm{b}} \pm 1.7$ & $-6.2^{\mathrm{b}} \pm 0.1$ & $32.0^{\mathrm{a}} \pm 0.2$ & $1.56^{\mathrm{a}} \pm 0.37$ \\
\hline
\end{tabular}

Results are expressed as mean \pm SD $(n=3)$. Same letters in the same column do not represent statistically significant differences $(\mathrm{p}<0.05)$ by Tukey test.

The carrot leaf or carrot leaf and lemon zest increased the antioxidant activity of the sponges cakes, this parameter in CLLZ cake $\left(1.73 \mu \mathrm{mol}\right.$ ET. $\left.\mathrm{g}^{-1}\right)$ and WCL $\left(1.48 \mu \mathrm{mol} \mathrm{ET} . \mathrm{g}^{-1}\right)$ was approximately duplicated in comparison with WOCL cake $\left(0.88 \mu\right.$ mol TE.g $\left.{ }^{-1}\right)$. Probably, antioxidant activity in CLLZ has increased because according Guimarães et al. (2010) lemon zest presents $116.25(\mathrm{mg} / \mathrm{mL})$ for antioxidant activity (DPPH).

In fact, the antioxidant activity on carrot leaf was reported (LEITE et al., 2011). A new food product, pasta, was elaborated with carrot leaf and an increment on antioxidant activity was observed (BOROSKI et al., 2011). Pereira et al. (2003) found levels of vitamin C and $\beta$-carotene in carrot leaf; they reported these compounds as agents antioxidants in foods.

\subsection{Color and Texture Instrumental Analysis}

The quality of cakes can be evaluated by sensory and instrumental means. The procedure for determining the firmness by instrumental methods and other parameters of texture on the cake is to slice samples, submit them to a texture compression mechanical and analyzing the resulting force-time curve (ESTELLER; AMARAL; LANNES, 2004).

Results of texture and color instrumental analyses are shown in the Table 3. No statistically significant differences among the samples for texture, with values of $1.31,1.56$ and $1.44 \mathrm{kgf}$ were observed for WOCL, WCL and CLLZ, respectively. Thus, it can be observed that the addition of carrot leaf, in the amount studied, did not influence the texture.

About the parameters of chromaticity ( $\mathrm{a}^{*}$ and $\mathrm{b}^{*}$ ), it was possible to affirm that the samples were in areas of green and yellow by reading colorimeter. There were significant differences between WCL and CLLZ, compared to the WOCL, due to the presence of pigments in leaves, which confers staining.

Was observed a reduction in luminosity parameter $\left(\mathrm{L}^{*}\right)$ due the darkening of cakes prepared with the addition of carrot leaf. The color of cakes is directly related to the ingredients contained in the formulation. Other factors can also influence the color of the cakes. The presence of sugar and eggs, as well as heat can accelerate the
Maillard browning reactions leading to progressive browning of the crust and crumb (GIESE, 2000).

\section{Conclusion}

The incorporation of carrot leaf in sponge cakes resulted in quality products that were a lot well accepted by children in school age. The sponge cakes that received carrot leaf had increase in antioxidant activity compared with the control sponge cake, which is desirable since there is a search for functional foods. Moreover, the use of by-products aggregates value to food, and can be introduced adequately to improve the nutritional and functional factors of food.

\section{References}

AL-SAYED, H. M. A.; AHMED, A. R. Utilization of watermelon rinds and sharlyn melon peels as a natural source of dietary fiber and antioxidants in cake. Annals of Agricultural Science, v. 58, n. 1, p. 83-95, 2013.

ALMEIDA, V. V.; BONAFÉ, E. G.; MUNIZ, E. C.; MATSUSHITA, M.; SOUZA, N. E.; VISENTAINER, J. V. Optimization of the carrot leaf dehydration aiming at the preservation of Omega-3 fatty acids. Química Nova, v. 32, n. 5, p. 1334-1337, 2009.

ANVISA - Agência Nacional de Vigilância Sanitária. Rotulagem Nutricional Obrigatória Manual de Orientação aos Consumidores Educação para o Consumo Saudável. Brasília: Ministério da Saúde, Agência Nacional de Vigilância Sanitária, Universidade de Brasília, 2001.

AOAC INTERNATIONAL. Official Methods of Analysis. 16th ed., Gaitherburg: AOAC, 1997.

AYALA-ZAVALA, J. F.; VEGA-VEGA, V.; ROSASDOMÍNGUES, C.; PALAFOX-CARLOS, H.; VILLARODRIGUEZ, J. A.; WASIM-SIDDIQUI, M. D.; DÁVILA-AVIÑA, J. E.; GONZÁLEZ-AGUILAR, G. A. Agro-industrial potential of exotic fruit byproducts as a source of food additives. Food Research International, v. 44, n. 7, p.1866-1874, 2011. 
BLASA, M.; GENNARI, L.; ARGELINO, D.; NINFALI, P. Chapter 3 - Fruit and Vegetable Antioxidants in Health. Bioactive Foods in Promoting Health, p. 37-58, 2010.

BLIGH, E. G.; DYER, W. J. A rapid method of total lipid extraction and purification. Canadian Journal of Biochemical and Physiology, v. 37, n. 8, p. 991-917, 1959.

BLOCK, G.; LANGSETH, L. Antioxidant vitamins and disease prevention. Food Technology, v. 52, n. 8, p. 266270, 1994.

BORGES, J. T. S.; PIROZI, M. R.; LUCIA, S. M. D.; PEREIRA, P.C.; MORAES, A. R. F.; CASTRO, V. C. Utilização de farinha mista de aveia e trigo na elaboração de bolos. Boletim Ceppa, v. 24, n. 1, p. 145$162,2006$.

BOROSKI, M.; AGUIAR, A. C.; BOEING, J. S.; ROTTA, E. M.; WIBBY, C. L.; BONAFÉ, E. G.; SOUZA, N. E.; VISENTAINER, J. V. Enhancement of pasta antioxidant activity with oregano and carrot leaf. Food Chemistry, v. 125, n. 2, p. 696-700, 2011.

BRAND-WILLIAMS, W.; CUVELIER, M. E.; BERSET, C. Use of a free radical method to evaluate antioxidant activity. LWT - Food Science and Technology, v. 28, n. 1, p. 25-30, 1995.

ESTELLER, M. S.; AMARAL, R. L.; LANNES, S. C. $S$. Effect of sugar and fat replacers on the texture of baked goods. Journal of Texture Studies. v. 35, p. 383393, 2004.

GIESE J. Color measurement in foods as a quality parameter. Food Technology. v. 54, n.2, p. 62-63, 2000.

Guimarães, R; Barros, L; Barreira, J; Sousa, M; Carvalho, A; Ferreira, I; Targeting excessive free radicals with peels and juices of Citrus fruits: Grapefruit, lemon, lime and Orange. Food Chemistry Toxicology, v. 48 , p. $99-106,2010$.

GUPTA, M.; BAWA, A. S.; SEMWAL, A. D. Effect of barley flour incorporation on the instrumental texture of sponge cake. International Journal of Food Properties, v. 12, n. 1, p. 243-251, 2009.

KIM, J. H.; LEE, H. J.; LEE, H. S.; LIM, E. J.; IMM, J. Y.; SUH, H. J. Physical and sensory characteristics of fibre-enriched sponge cakes made with Opuntia humifusa. LWT - Food Science and Technology, v. 47, n. 2, p. 478-484, 2012.

LEITE, C. W.; BOROSKI, M., BOIENG, J. S.; AGUIAR, A. C.; FRANÇA, P. B.; SOUZA, N. E., VISENTAINER, J. E. Chemical characterization of leaves of organically carrot (Daucus carota L.) in various stages of development for use as food. Ciência e Tecnologia de Alimentos, v. 31, n. 3, p. 735-738, 2011.

LU, T. M.; LEE, C. C.; MAU, J. L.; LIN, S. D. Quality and antioxidant property of green tea sponge cake. Food Chemistry, v. 119, n. 3, p. 1090-1095, 2010.
MCGUIRE, R. G. Reporting of objective color measurements. Hortscience, v. 27, n. 12, p. 1254-1255, 1992.

MONTEIRO, A.R.G. Introdução à análise sensorial de alimentos. Editora da Universidade Estadual de Maringá, EDUEM, 2005.

MORAES, E. A.; DANTAS, M. I. S.; MORAIS, D.C.; SILVA, C. O.; CASTRO, F. A. F.; MARTINO, H. S. D.; RIBEIRO, S. M. R. Sensory evaluation and nutritional value of cakes prepared with whole flaxseed flour. Ciência e Tecnologia de Alimentos, v. 30, n. 4, p. 974-979, 2010.

NANDITHA, B.; PRABHASANKAR, P. Antioxidants in bakery products: A review. Critical Reviews in Food Science and Nutrition, v. 49, p. 1-27, 2009.

O'SHEA, N.; ARENDT, E. K.; GALLAGHER, E. Dietary fibre and phytochemical characteristics of fruit and vegetable by-products and their recent applications as novel ingredients in food products. Innovative Food Science and Emerging Technologies, v. 16, p. 1-10, 2012.

PEREIRA, G. I. S.; PEREIRA, R. G. F. A.; BARCELOS, M. F. P.; MORAIS, A. R. Carrot leaf chemical evaluation aiming its use in human feeding. Ciência e Agrotecnologia, v. 27, n. 4, p. 852-857, 2003.

RODRÍGUEZ-GARCIA, J.; PUIG, A.; SALVADOR, A.; HERNANDO, I. Optimization of a sponge cake formulation with inulin as fat replacer: structure, physicochemical, and sensory properties. Journal of Food Science, v. 77, p. 189-197, 2012.

RONDA, F.; GÓMEZ, M.; BLANCO, C. A.; CABALLERO, P. A. Effects of polyols and nondigestible oligosaccharides on the quality of sugarfree sponge cakes. Food Chemistry, v. 90, n. 4, p. 549$555,2005$.

SALAWU, S. O.; SANNI, D. M.; AKINDAHUNSI, A. A. HPLC/DAD/MS phenolic profile, antioxidant activities and inhibitory action of struchium sparganophora (Linn) and telfairia occidentalis (Hook. F) against low density lipoprotein oxidation. African Journal of Food Science and Technology, v. 4, p. 1-8, 2013.

SCALBERT, A.; MANACH, C.; MORAND, C.; REMESY, C. Dietary polyphenols and the prevention of diseases. Critical Reviews in Food Science and Nutrition, v. 45, p. 287-306, 2005.

ZHANG, Y.; SONG, Y.; HU, X.; LIAO, X.; NI, Y.; LI, Q. Effects of sugars in batter formula and baking conditions on 5-hydroxymethylfurfural and furfural formation in sponge cake models. Food Research International, v. 49, n. 1, p. 439-445, 2012. 